Social Sciences, Humanities and Education Journal (SHE Journal)

Volume 1 (3) 58 - 67, September 2020 | ISSN: 2720-9946 (Online) | ISSN: 2723-3626 (Print)

The article is published with Open Access at: http://e-journal.unipma.ac.id/index.php/SHE

\title{
IMPROVING SO CIAL SKILL AND CIVICS LEARNING OUTCOME THROUGH PROBLEM -BASED LEARNING (PBL) ASSISSTED WITH DIGITAL LITERACY TO THE XI GRADERS OF TITL VOCATIONAL HIGH SCHOOL SMK GAMALIEL 1 MADIUN
}

\author{
Basuki $₫$, Universitas PGRI Madiun. \\ Sudarmiani, Universitas PGRI Madiun. \\ Moh. Rifa'I, Universitas PGRI Madiun.
}

\begin{abstract}
The current study, which is a classroom action research, aims to improve: (1) the learning process; and (2) the social skill and civics learning outcome of the XI graders of TITL vocational high school of SMK Ga maliel 1 Madiun through implementing PBL assisted by di gital literacy. This involved 35 students and lasted from August 2019 to February 2020. Data were gathered through (1) interview, (2) observation, (3) document, (4) assignments/tests. On the basis of $t$ he 4 cycles, it was found that the average score of the social skill of: cycle 1 was 61.23 ; cycle 2 was 72.03 ; cycle 3 was 82.09. There was improvement as much as 10.80 from cycle 1 to cycle 2 , and 10.06 from cycle 2 to cycle 3 . Regarding learning outcome, the average scores were: cycle $1=65.00$; cycle $2=71.14$, and cycle $3=76.71$. There were, therefore, improvement as much as 6.15 from cycle 1 to cycle 2 and 5.57 from cycle 2 to cycle 3 . To put in brief, implementing PBL assisted by digital literacy to the XI graders of TITL vocational high school of SMK Gamaliel 1 Madiun improved their: (1) social skill, and (2) civics learning outcome.
\end{abstract}

Keywords: Social Skill, Civics, Learning Outcome, Digital Literacy.

$\bowtie$ stevanusbasuki@yahoo.co.id

Citation: Basuki, B., Sudarmiani, S., \& Rifai, M. (2020). Improving social skill and civics learning outcome through problem -based learning (PBL) assissted with digital literacy to the XI graders of titl vocational high school SMK gamaliel 1 madiun . Social Scienc es, Humanities and Education Journal (SHE Journal), 1(3), 58 - 67. DOI: 10.25273/she.v1i3.7565

\section{(c) $\overline{E Y-N C-S A}$}

Published by Universitas PGRI Madiun. This work is licensed under the Creative Commons Attribution NonCommercialShareAlike 4.0 International License. 


\section{PENDAHULUAN}

Tuntutan perubahan mendasar di atas direspon oleh berbagai elemen dalam masyarakat, termasuk elemen fundamental, yaitu pendidikan yang bertanggung jawab untuk mengembangkan manusia-manusia, warga negara/warga masyarakat yang memiliki ciri-ciri seperti dikemukakan di atas. Pendidikan sebagai elemen dalam proses perubahan bermasyarakat, berbangsa dan bernegara, sebagaimana ditegaskan dalam rumusan Pasal 3 UU No. 20 Tahun 2003 tentang Sistem Pendidikan kemampuan dan membentuk watak serta peradaban bangsa yang bermartabat dalam rangka mencerdaskan kehidupan bangsa "berkembangnya potensi peserta didik aga bertakwa kepada Tuhan Yang Maha Esa, berakhlak mulia, sehat, berilmu, cakap, kreatif, mandiri, dan menjadi warganegara yang demokratis serta bertanggung jawab".

Kualitas pendidikan merupakan aspek terpenting dalam usaha pembangunan yang sedang dilaksanakan di Indonesia. Mutu pendidikan juga dipengaruhi oleh kurikulum yang diterapkan dalam pendidikan nasional. Undang-Undang Nomor 20 Tahun 2003 Tentang Sistem Pendidikan Nasional Pasal 35 ayat (1) menjelaskan bahwa untuk menilai mutu pendidikan di Indonesia dilihat dengan delapan kriteria, yaitu isi (kurikulum), proses pembelajaran, kompetensi lulusan, tenaga pendidik, sarana prasarana, pengelola pendidikan, pembiayaan pendidikan dan penilaian pendidikan. Tujuan Pendidikan Nasional menurut Undang-Undang Nomor 20 tahun 2003 pasal 3 disebutkan bahwa: Tujuan pendidikan nasional adalah untuk berkembangnya potensi peserta didik agar manusia yang beriman, bertakwa kepada Tuhan Yang Maha Esa, berakhlak mulia, sehat, berilmu, cakap, kreatif, mandiri dan menjadi warga negara yang demokratis serta bertanggungjawab. Sekolah Menengah Kejuruan atau yang akrab disingkat dengan SMK adalah suatu lembaga pendidikan tingkat menengah dimana peserta didik (siswa) sebagai input, dididik dan dilatih agar memiliki keterampilan dan mampu memenuhi tuntutan zaman serta bersaing dalam dunia kerja. Untuk mampu bersaing dan hidup dengan selaras dalam dunia kerja, siswa tidak hanya dibekali dengan kemampuan akademik, diharapkan seluruh siswa memiliki keterampilan sosial yang tinggi. Oleh sebab itu, lulusan SMK harus dibekali keterampilan sosial yang memadai dan sangat penting dalam bersosialisasi dan berinteraksi antarsesama manusia, baik dalam hal berkomunikasi maupun bertingkah laku dengan orang lain.

Menurut Malikeh Beheshtifar (213:2) memberikan berpendapat bahwa: "Social skills can be defined as the set of skills people use to interact and communicate with one another. They are based on the social norms of our society and they tell us what attitudes and behaviors are considered to be normal, acceptable and expected in a particular social situation. Artinya bahwa sebagai serangkaian keterampilan yang digunakan orang untuk berinteraksi dan berkomunikasi dengannya lain. Mereka didasarkan pada norma sosial masyarakat kita dan mereka memberi tahu kita apa sikap dan perilaku dianggap normal, dapat diterima dan diharapkan dalam situasi sosial tertentu. Lebih lanjut, keterampilan sosial dibagi dalam empat kategori, yakni: (1) environmental behavior; (2) interpersonal behavior; (3) self-related behavior; dan (4) task-related behavior (Saripah \& Mulyani, 2015: 153).

Izzaty (2007: 5) menyatakan tiga aspek keterampilan sosial yang perlu ditanamkan dari sejak usia dini, yaitu: (1) Empati, meliputi penuh pengertian, tenggang rasa, kepedulian pada orang lain. (2) Afilasi dan resolusi konflik, meliputi komunikasi dua arah, kerja sama, penyelesaian konflik. (3) Mengembangkan kebiasaan positif, meliputi tata krama, kemandirian, tanggung jawab. Hal ini juga sesuai dengan pendapat dari Cartledge dan Milbum dalam Maryani (2011: 17) yang menyatakan bahwa: "Keterampilan sosial merupakan perilaku yang dapat dipelajari, karena memungkinkan individu dapat berinteraksi, mempengaruhi respon positif 
dan negatif. Keterampilan ini sangat dibutuhkan di kehidupan yang akan datang dalam menjalani hubungan sosial di masyarakat". Gresham dan Reschly (dalam Gimpel dan Merrel, 1988) mengidentifikasikan keterampilan sosial dengan beberapa ciri, antara lain: (1) perilaku interpersonal; (2) Perilaku yang Berhubungan dengan Diri Sendiri, (3) Perilaku yang Berhubungan dengan Kesuksesan Akademis; (4) Penerimaan Teman Sebaya; (5) keterampilan berkomunikasi. Adapun ciri-ciri individu yang memiliki keterampilan sosial, menurut Eisler dkk (L"Abate \& Milan, 1985) adalah orang yang berani berbicara, memberi pertimbangan yang mendalam, memberikan respon yang lebih cepat, memberikan jawaban secara lengkap, mengutarakan bukti-bukti yang dapat meyakinkan orang lain, tidak mudah menyerah, menuntut hubungan timbal balik,serta lebih terbuka dalam mengekspresikan dirinya. Sementara Philips (dalam L"Abate \& Milan, 1985) menyatakan "Ciri-ciri individu yang memiliki keterampilan sosial meliputi: proaktif, prososial, saling memberi dan menerima secara seimbang".

Keterampilan sosial dapat dilatih melalui belajar, Muhibbin menyebutkan bahwa seorang ahli psikolog bernama Wittig dalam bukunya psychology of learning mendefinisikan belajar sebagai: "any relatively permanent change in an organism's behavioral repertoire that occurs as a result of experience, artinya belajar adalah perubahan yang relatif menetap yang terjadi dalam segala macam atau keseluruhan tingkah laku suatu organisme sebagai hasil pengalaman". Hasil belajar ada 3 (tiga) yaitu sikap, pengetahuan dan keterampilan. Maka dari itu, keterampilan sosial merupakan salah satu hasil belajar. Hasil belajar akan maksimal bila guru dalam proses pembelajaran mampu menerapkan model pembelajaran yang sesuai dengan tujuan dan isi materi yang akan diajarkan kepada peserta didik. Salah satu model pembelajaran yaitu model pembelajaran Problem based Learning (PBL). Barrow dalam Huda (2013: 271) mendefinisikan pembelajaran berbasis masalah (Problem Based Learning/PBL) sebagai pembelajaran yang diperoleh melalui proses menuju pemahaman akan resolusi suatu masalah. Melalui model pembelajaran PBL siswa akan terlibat dalam kegiatan pemecahan masalah dan tugas-tugas bermakna lainnya. Ibrahim dan Nur dalam Rusman (2014: 241) menyatakan bahwa model pembelajaran Problem Based Learning (PBL) merupakan salah satu model pembelajaran yang digunakan untuk merangsang berpikir tingkat tinggi siswa dalam situasi yang berorientasi pada masalah dunia nyata, termasuk di dalamnya belajar bagaimana belajar. Ada beberapa langkah dalam menerapkan model pembelajaran Problem Based Learning (PBL). Arends dalam Ngalimun (2012: 96) mengemukakan lima fase yang perlu dilakukan untuk mengimplementasikan model Problem Based Learning (PBL), meliputi: (1) Orientasi siswa pada masalah, (2) mengorganisasi siswa untuk belajar, (3) membimbing pengalaman individual/kelompok, (4) mengembangkan dan menyajikan hasil karya, (5) menganalisis dan mengevaluasi proses pemecahan masalah. Problem based Learning (PBL) merupakan salah satu model pembelajaran yang berkembang dari pendekatan scintific. Problem Based Learning (PBL) merupakan model pembelajaran yang berpusat pada siswa di mana siswa dikondisikan untuk aktif mencari alternative pemecahan masalah yang diberikan dengan menggunakan idel dan gagasan yang dimiliki oleh siswa. Masalah yang diberikan dalam pembelajaran merupakan masalah seharihari yang terjadi dilingkungan sekitar siswa.

Di era sekarang ini model pembelajaran yang digunakan guru dalam pembelajaran didukung sejauhmana peserta didik memanfaatkan literasi berbasis terknologi informasi dalam memperoleh mengembangkan ilmunya. Melalui literasi digital untuk menunjukkan konsep yang luas yang menautkan bersama-sama berbagai literasi yang 
relevan serta literasi berbasis kompetensi dan ketrampilan teknologi komunikasi, namun menekankan pada kemampuan evaluasi informasi yang lebih "lunak" dan perangkaian pengetahuan bersama-sama pemahaman dan sikap (Bawden, 2008; Martin, 2006, 2008) . Literasi digital mencakup pemahaman tentang Web dan mesin pencari. Pemakai memahami bahwa tidak semuainformasi yang tersedia di Web memiliki kualitas yang sama; dengan demikian pemakai lambat laun dapat mengenali situs Web mana yang andal serta situs mana yang tidak dapat dipercayai. Dalam literasi digital ini pemakai dapat memilih mesin pemakai yang baik untuk kebutuhan informasinya, 9 mampu menggunakan mesin pencari secara efektif (misalnya dengan "advanced search". Melalui literasi dapat membangkitkan peserta didik belajar mandiri. Menurut Hiemstra (1994:1) belajar mandiri maksudkan untuk membangun budaya belajar yang dikonstruk dari peserta didik itu sendiri. Inisiatif serta tujuan belajar, dan juga cara belajar ditentukan oleh peserta didik sendiri. Hal ini dapat dilakukan oleh tenaga pendidik untuk mengarahkan peserta didik dalam mengembangkan kemampuan belajar siswanya.

Berdasarkan hasil pengamatan dilapangan terlihat bahwa keterampilan sosial siswa masih kurang. Hal tersebut terlihat dari capaian setiap indikator yang menunjukkan capaian kurang. Berikut ulasan selama proses pembelajaran yang terjadi selama ini, terlihat siswa kurang begitu aktif dalam proses pembelajaran, ketika guru memberi kesempatan bertanya siswa hanya terdiam, dan ketika guru mengajukan pertanyaan kepada siswa siswa cenderung diam (terlihat tidak paham atas materi yang disampaikan oleh guru). Proses pembelajaran yang terjadi di dalam kelas kurang menarik karena terpusat pada guru hal tersebut mempengaruhi menurunnya tingkat keterampilan sosial yang terjadi selama proses pembelajaran, siswa hanya mengikuti alur saja tanpa berpikir secara mendalam terkait materi yang disampaikan oleh guru. Selama ini guru kurang melibatkan siswa dalam proses pembelajaran akibatnya siswa terlihat malas-malasan (menerima saja).

Pembelajaran di kelas masih didominasi oleh guru hal tersebut berdampak mengurangi ruang gerak siswa untuk mengembangkan pola pikirnya. Menindaklanjuti hal yang terjadi maka Penulis memberikan beberapa solusi untuk mengatasi masalah-masalah tersebut, yaitu dengan merubah pola pembelajaran yang tadinya guru sebagai pusat dirubah menjadikan siswa yang menjadi pusat dengan harapan guru memberikan kesempatan untuk siswa agar lebih aktif dalam kegiatan pembelajaran, hal tersebut diharapkan akan memacu motivasi siswa dalam proses pembelajaran. Selain itu guru juga bisa menerapkan berbagai model pembelajaran dengan tujuan untuk menciptakan situasi belajar yang lebih menarik hal tersebut secara otomatis mempengaruhi hasil belajar serta keterampilan sosial meningkat. Model pembelajaran yang diduga dapat meningkatkan keterampilan sosial yaitu Model Pembelajaran Problem Based Lerning ( $P B L$ ) berbantuan Literasi Digital yang diharapkan mampu menarik minat belajar siswa dengan menitikberatkan serta mengharuskan siswa mampu mengikuti perkembangan jaman dan lebih aktif selama proses belajar memakai Jaringan Internet. Temuan mengenai keterampilan sosial siswa SMK yang begitu kurang memuaskan, berharap model Pembelajaran Problem Based Learning (PBL) berbantuan Literasi Digital dapat mengatasi permasalahan yang terjadi selama proses pembelajaran serta mengubah motivasi serta minat siswa untuk lebih aktif dalam proses pembelajaran, salain itu model pemebelajaran tersebut memiliki keunggulan untuk meningkatkan keterampilan sosial siswa yang menjadi fokus di dalam penelitian ini, dengan harapan melalui model tersebut keterampilan sosial siswa akan meningkat.

Melalui literasi digital saat ini memperoleh informasi sangat mudah. Media digital memudahkan setiap 
penggunanya untuk saling berbagi informasi. Sumber informasi bisa berasal darimana saja. Era digital tidak dapat dielakkan lagi. Siapapun dapat dengan mudah memanfaatkannya dengan baik, namun tidak jarang juga dapat menghancurkan seseorang. Ketidakpahaman masyarakat terhadap media digital membuat penyalahgunaan yang berakibat terhadap kehidupan pribadi dan sosial. Media sosial hadir sebagai bagian dari perkembangan internet. Kehadirannya menawarkan cara berinteraksi, berkomunikasi, dan bersosialisasi yang mudah dan baru dengan dukungan fitur yang menarik, hal ini diharapkan dapat meningkatkan keterampilan siswa sehingga dapat dijadikan bekal untuk terjun di dunia usaha/dunia industri.

Berdasarkan uraian di atas menarik untuk diteliti yaitu: (1) proses pembelajaran dengan menggunakan Pendekatan Problem Based Learning (PBL) berbantuan Literasi Digital pada siswa kelas XI-TITL SMK Gamaliel 1 Madiun; (2) model pendekatan Problem Based Learning (PBL) berbantuan Literasi Digital dapat meningkatkan keterampilan sosial dan hasil belajar PPKn siswa kelas XI-TITL SMK Gamaliel 1 Madiun.

\section{METODE PENELITIAN}

\section{Penelitian ini}

Penelitian Tindakan

menggunakan dilaksanakan melalui empat langkah utama yang saling berkaitan, yaitu: a) Perencanaan Tindakan, b) Pelaksanaan Tindakan, c) Observasi, dan d) Refleksi., subjek penelitian ini adalah siswa kelas XI TITL SMK Gamaliel 1 Madiun tahun pelajaran 2019/2020 yang berjumlah 35 siswa. Teknik pengumpulan data yang digunakan dalam penelitian ini, antara lain dengan menggunakan: (1) Wawancara, (2) Observasi, (3) Dokumentasi dan (4) tes.

Indikator yang ingin dicapai dalam penelitian ini adalah meningkatnya Keterampilan Sosial dan Hasil Belajar Siswa Kelas XI-TITL SMK Gamaliel 1 Madiun melalui pengoptimalan penerapan model pembelajaran Problem Based Learning
$(P B L)$ berbantuan Literasi Digital. Setiap tindakan upaya peningkatan indikator tersebut dirancang dalam satu unit sebagai satu siklus. Setiap siklus terdiri dari empat tahap, yaitu: (1) Perencanaan Tindakan, (2) Pelaksanaan Tindakan, (3) Observasi dan Interpretasi, dan (4) Analisis dan Refleksi untuk perencanaan siklus berikutnya.

Indikator Kinerja keterampilan sosial baik secara partisial peserta didik telah mencapai Ketuntasan Minimal jika memperoleh skor 70, dan secara klasikal $70 \%$ peserta didik telah mencapai mencapai Kriteria Ketuntasan Minimal (KKM). Demikian juga, peserta didik dikatakan tuntas hasil belajar jika telah memperoleh nilai minimal 70, dan secara klasikal jika 70\% peserta didik telah mencapai kriteria ketuntasan minimal.

Teknik yang digunakan untuk menganalisis data penelitian ini adalah teknik kuantitatif dan teknik kualitatif. Hasil yang diperoleh keseluruhan siswa pada siklus I dibandingkan dengan hasil yang diperoleh keseluruhan siswa pada siklus II untuk mengetahui peningkatan Keterampilan Sosial dan Hasil Belajar PPKn Kelas XI-TITL SMK Gamaliel 1 Madiun.

Teknik kualitatif dipakai untuk menganalisis data-data nontes, yaitu data observasi atau pengamatan. Data observasi dianalisis untuk mendeskripsikan sikap siswa dalam mengikuti pelajaran. Dari data ini diketahui perubahan sikap siswa selama mengikuti pelajaran pada siklus ke siklus yang lain. Analisis kualitatif penelitian ini peneliti mengadopsi teknik Miles dan Hubberman dalam Suwarsih Madya (1994:76) dapat digolongkan dalam tiga alur kegiatan yang terjadi secara interaktif, meliputi (1) Reduksi data; (2). Sajian data; dan (3) Menarik kesimpulan dan verifikasi.

\section{HASIL PENILITIAN DAN PEMBAHASAN}

\section{Hasil Penelitian}

a. SIklus I

Hasil capaian keterampilan sosial siswa secara parsial pada Siklus I dapat dituangkan dalam tabel di bawah ini. Berdasarkan hasil rekapitulasi pengamatan keterampilan sosial siswa secara parsial diperoleh hanya 1 aspek yang telah 
mencapai tuntas, selebihnya belum secara klasikal dapat dilihat dalam tabel mencapai kriteria ketuntasan minimal. berikut ini. Kemudian hasil rekapitulasi pengamatan

Tabel 1. Hasil pengamatan Keterampilan Sosial secara parsial Siklus I

\begin{tabular}{clcc}
\hline No & \multicolumn{1}{c}{ Indikator } & Skor & Keterangan \\
\hline 1 & Kemampuan berbagi informasi & 51 & belum tuntas \\
2 & Kemampuan berbicara secara bergiliran & 58 & belum tuntas \\
3 & Kemampuan menyampaikan pendapat & 68 & belum tuntas \\
4 & Kemampuan bekerja sama & 66 & belum tuntas \\
5 & Kemampuan saling menolong & 72 & tuntas \\
6 & Kemampuan menyelesaikan masalah dengan berdiskusi & 65 & belum tuntas \\
7 & Kemampuan menerima/respek terhadap pendapat & 62 & belum tuntas \\
& orang lain & & \\
\hline
\end{tabular}

Tabel 2. Hasil Pengamatan Keterampilan Sosial Siklus I

\begin{tabular}{cccccl}
\hline No. & Nilai & Kategori & f & $\mathbf{\%}$ & \multicolumn{1}{c}{ Hasil Klasikal } \\
\hline 1. & $<45$ & Sangat Kurang & 1 & $2.86 \%$ & 35 siswa mencapai nilai \\
2. & $46-60$ & Kurang & 16 & $45.71 \%$ & total skor 2143 dengan \\
3. & $61-75$ & Cukup & 17 & $48.57 \%$ & rata-rata nilai 61.2 dalam \\
4 & $76-90$ & Baik & 0 & $0.00 \%$ & kategori cukup. \\
5. & $>91$ & Sangat baik & 1 & $2.86 \%$ & \\
& & Jumlah & 35 & $100,00 \%$ & \\
\hline
\end{tabular}

Tabel 3. Hasil belajar online berbasis aplikasi moodle (siklus I)

\begin{tabular}{cccccl}
\hline No. & Nilai & Kategori & f & \% & Hasil Klasikal \\
\hline 1. & $<59$ & Perlu dimaksimalkan & 11 & $31.43 \%$ & 35 siswa mencapai nilai \\
2. & $60-73$ & Cukup & 16 & $45.71 \%$ & total skor 2275 dengan \\
3. & $74-87$ & Baik & 8 & $22.86 \%$ & rata-rata nilai 65 dalam \\
4 & $>88$ & Baik Sekali & 0 & $0.00 \%$ & kategori cukup. \\
& & 35 & $100,00 \%$ & \\
\hline
\end{tabular}

Tabel 4. Hasil pengamatan Keterampilan Sosial secara parsial Siklus II

\begin{tabular}{clcc}
\hline No & \multicolumn{1}{c}{ Indikator } & Skor & Keterangan \\
\hline 1 & Kemampuan berbagi informasi & 62 & belum tuntas \\
2 & Kemampuan berbicara secara bergiliran & 67 & belum tuntas \\
3 & Kemampuan menyampaikan pendapat & 74 & tuntas \\
4 & Kemampuan bekerja sama & 72 & tuntas \\
5 & Kemampuan saling menolong & 77 & tuntas \\
6 & Kemampuan menyelesaikan masalah dengan berdiskusi & 79 & tuntas \\
7 & Kemampuan menerima/respek terhadap pendapat & 73 & tuntas \\
& orang lain & & \\
\hline
\end{tabular}

Sebanyak 1 siswa atau 2,86\% pada kategori sangat kurang, 16 siswa atau $45,71 \%$ pada kategori kurang, 17 siswa atau $48,57 \%$ pada kategori cukup dan 1 siswa atau $2,86 \%$ pada kategori baik sekali. Secara klasikal 35 siswa tersebut mencapai total nilai 2143 dengan nilai rata-rata 61,2 dalam kategori cukup.

Setelah pembelajaran diakhiri, maka siswa diberi tugas untuk mengerjakan soal
Pilihan ganda melalui pembelajaran daring (dalam jaringan) menggunakan aplikasi moodle yang dikerjakan secara mandiri di rumah. Hasil tes pilihan ganda yang dilaksanakan secara online berbasis moodle pada siswa kelas XI TITL SMK Gamaliel 1 Madiun dapat dituangkan dalam tabel berikut ini.

Berdasarkan hasil tes pilihan ganda sebanyak 11 siswa atau $31,43 \%$ pada 
kategori perlu dimaksimalkan, 16 siswa atau $45,71 \%$ pada kategori cukup, 8 siswa atau $22,86 \%$ pada kategori baik dan 0 siswa atau $0,00 \%$ pada kategori baik sekali. Secara klasikal 35 siswa tersebut mencapai total nilai 2275 dengan nilai rata-rata 65,00 dalam kategori cukup.

b. Siklus II

Hasil capaian keterampilan sosial siswa Secara parsial pada Siklus II dapat dituangkan dalam tabel di bawah ini.
Berdasarkan hasil rekapitulasi pengamatan keterampilan sosial siswa secara parsial diperoleh hanya 5 aspek keterampilan sosial yang telah mencapai tuntas, dan 2 aspek yang belum mencapai kriteria ketuntasan minimal. Kemudian hasil rekapitulasi pengamatan secara klasikal dapat dilihat dalam tabel berikut ini.

Tabel 5. Hasil Pengamatan Keterampilan Sosial Siklus II

\begin{tabular}{cccccl}
\hline No. & Nilai & Kategori & f & $\mathbf{\%}$ & \multicolumn{1}{c}{ Hasil Klasikal } \\
\hline 1. & $<45$ & Sangat Kurang & 0 & $0.00 \%$ & 35 siswa mencapai nilai \\
2. & $46-60$ & Kurang & 4 & $11.43 \%$ & total skor 2519 dengan \\
3. & $61-75$ & Cukup & 19 & $54.29 \%$ & rata-rata nilai 72.0 dalam \\
4 & $76-90$ & Baik & 11 & $31.43 \%$ & kategori baik. \\
5. & $>91$ & Sangat baik & 1 & $2.86 \%$ & \\
& & Jumlah & 35 & $100,00 \%$ & \\
\hline
\end{tabular}

Pada Siklus II ini sebanyak 4 siswa atau $11,43 \%$ pada kategori kurang, sebanyak 19 siswa atau $54,29 \%$ pada kategori cukup, sebanyak 11 siswa atau $31,43 \%$ pada kategori baik dan 1 siswa atau $2,86 \%$ pada kategori baik sekali. Secara klasikal 35 siswa tersebut mencapai total nilai 2521 dengan nilai rata-rata 72 dalam kategori baikSetelah pembelajaran diakhiri, maka siswa diberi tugas untuk mengerjakan soal Pilihan ganda melalui pembelajaran daring (dalam jaringan) menggunakan aplikasi moodle yang dikerjakan secara mandiri di rumah. Hasil tes pilihan ganda yang dilaksanakan secara online berbasis moodle pada siswa kelas XI TITL SMK Gamaliel 1 Madiun dapat dituangkan dalam tabel berikut ini.

Tabel 6. Hasil belajar online berbasis aplikasi moodle (siklus II)

\begin{tabular}{cccccl}
\hline No. & Nilai & Kategori & f & \% & Hasil Klasikal \\
\hline 1. & $<59$ & Perlu dimaksimalkan & 2 & $5.71 \%$ & 35 siswa mencapai nilai total \\
2. & $60-73$ & Cukup & 18 & $51.43 \%$ & skor 2490 dengan rata-rata \\
3. & $74-87$ & Baik & 15 & $42.86 \%$ & nilai 71,14 dalam kategori baik. \\
4 & $>88$ & Baik Sekali & 0 & $0.00 \%$ & \\
& & Jumlah & 35 & $100,00 \%$ & \\
\hline
\end{tabular}

Berdasarkan hasil tes pilihan ganda pada siklus II sebanyak 2 siswa atau 5,71\% pada kategori perlu dimaksimalkan, 18 siswa atau $51,43 \%$ pada kategori cukup, 15 siswa atau $42,86 \%$ pada kategori baik dan 0 siswa atau $0,00 \%$ pada kategori baik sekali. Secara klasikal 35 siswa tersebut mencapai total nilai 2490 dengan nilai ratarata 71,14 dalam kategori cukup.

c. Siklus III

Hasil capaian keterampilan sosial siswa Secara parsial pada Siklus III dapat dituangkan dalam tabel di bawah ini.

Tabel 7. Hasil pengamatan Keterampilan Sosial secara parsial Siklus III

\begin{tabular}{clcc}
\hline No & \multicolumn{1}{c}{ Indikator } & Skor & Keterangan \\
\hline 1 & Kemampuan berbagi informasi & 77 & tuntas \\
2 & Kemampuan berbicara secara bergiliran & 73 & tuntas \\
3 & Kemampuan menyampaikan pendapat & 77 & tuntas \\
4 & Kemampuan bekerja sama & 97 & tuntas
\end{tabular}


$5 \quad$ Kemampuan saling menolong

6 Kemampuan menyelesaikan masalah dengan berdiskusi

7 Kemampuan menerima/respek terhadap pendapat orang lain

$\begin{array}{ll}91 & \text { tuntas } \\ 88 & \text { tuntas } \\ 73 & \text { tuntas }\end{array}$

Berdasarkan hasil rekapitulasi pengamatan keterampilan sosial siswa secara parsial diperoleh hanya seluruh aspek keterampilan sosial telah mencapai tuntas. Kemudian hasil rekapitulasi pengamatan secara klasikal dapat dilihat dalam tabel berikut ini.

Tabel 8. Hasil Pengamatan Keterampilan Sosial Siklus III

\begin{tabular}{cccccl}
\hline No. & Nilai & Kategori & f & \% & \multicolumn{1}{c}{ Hasil Klasikal } \\
\hline 1. & $<45$ & Sangat Kurang & 0 & $0.00 \%$ & 35 siswa mencapai nilai total \\
2. & $46-60$ & Kurang & 0 & $0.00 \%$ & skor 2873 dengan rata-rata \\
3. & $61-75$ & Cukup & 7 & $20.00 \%$ & nilai 82.1 dalam kategori baik. \\
4 & $76-90$ & Baik & 25 & $71.43 \%$ & \\
5. & $>91$ & Sangat baik & 3 & $8.57 \%$ & \\
& & Jumlah & 35 & $100,00 \%$ & \\
\hline
\end{tabular}

Pada Siklus III ini sebanyak 0 siswa atau $0,00 \%$ pada kategori kurang, sebanyak 7 siswa atau $20,00 \%$ pada kategori cukup, sebanyak 25 siswa atau $71,43 \%$ pada kategori baik dan 3 siswa atau 8,57\% pada kategori baik sekali. Secara klasikal 35 siswa tersebut mencapai total nilai 2873 dengan nilai rata-rata 82,1 dalam kategori baik. Setelah pembelajaran diakhiri, maka siswa diberi tugas untuk mengerjakan soal Pilihan ganda melalui pembelajaran daring (dalam jaringan) menggunakan aplikasi moodle yang dikerjakan secara mandiri di rumah. Hasil tes pilihan ganda yang dilaksanakan secara online berbasis moodle pada siswa kelas XI TITL SMK Gamaliel 1 Madiun dapat dituangkan dalam tabel berikut ini.

Tabel 9. Hasil belajar online berbasis aplikasi moodle (siklus III)

\begin{tabular}{cccccl}
\hline No. & Nilai & Kategori & f & $\%$ & \multicolumn{1}{c}{ Hasil Klasikal } \\
\hline 1. & $<59$ & Perlu dimaksimalkan & 0 & $0.00 \%$ & 35 siswa mencapai nilai total \\
2. & $60-73$ & Cukup & 10 & $28.57 \%$ & skor 2685dengan rata-rata \\
3. & $74-87$ & Baik & 21 & $60.00 \%$ & nilai 76,71 dalam kategori \\
4 & $>88$ & Baik Sekali & 4 & $11.43 \%$ & baik. \\
& & 35 & $100,00 \%$ & \\
\hline
\end{tabular}

Berdasarkan hasil tes pilihan ganda pada siklus III 10 siswa atau $28,57 \%$ pada kategori cukup, 21 siswa atau 60,00\% pada kategori baik dan 4 siswa atau 11,43\% pada kategori baik sekali. Secara klasikal 35 siswa tersebut mencapai total nilai 2685 dengan nilai rata-rata 76,71 dalam kategori baik.

\section{Pembahasan}

Peningkatan keterampilan Sosial siswa yang meliputi 7 (tujuh) aspek didalamnya. Sebagai gambaran, peroleh skor rerata aspek keterampilan sosial pada siklus I, II dan III beserta perbandingan dan peningkatan tiap-tiap aspek secara parsial dapat disajikan dalam tabel berikut ini.

Tabel 10. Perbandingan skor tiap-tiap aspek keterampilan sosial

\begin{tabular}{|c|c|c|c|c|c|c|c|c|c|}
\hline \multirow{2}{*}{ No. } & \multirow{2}{*}{ Siklus } & \multicolumn{7}{|c|}{ Kategori*) } & \multirow{2}{*}{ Skor Rata-rata } \\
\hline & & 1 & 2 & 3 & 4 & 5 & 6 & 7 & \\
\hline 1. & Siklus I & 55 & 51 & 61 & 70 & 64 & 65 & 62 & 61,2 \\
\hline 2. & Siklus II & 62 & 67 & 74 & 72 & 77 & 79 & 73 & 72,0 \\
\hline 3. & Siklus III & 77 & 73 & 77 & 97 & 91 & 88 & 73 & 82,1 \\
\hline
\end{tabular}




\begin{abstract}
Perbandingan peroleh pengamatan keterampilan

berbantuan literasi digital secara klasikal dari siklus I, II dan III terjadi peningkatan rata-rata secara keseluruhan yaitu pada siklus I rata-rata skor 61,2 meningkat menjadi 72,0 pada siklus II, dan meningkat ke siklus III menjadi 81,2. Hal ini menunjukkan bahwa terdapat peningkatan keterampilan sosial. Demikian juga, hasil belajar secara klasikal ada peningkatan rata-rata yaitu pada siklus I rata-rata klasikal 65.00 meningkat menjadi 72.00 pada siklus II dan meningkat menjadi 76.71 pada siklus III. Hal ini menunjukkan bahwa terdapat peningkatkan hasil belajar siswa kelas XI TITL SMK Gamaliel 1 Madiun tahun pelajaran 2019/2020.
\end{abstract}

hasil DAFTAR PUSTAKA

\section{SIMPULAN}

Dari hasil analisis data dapat disimpulkan bahwa: (1) Penerapan model pembelajaran Problem Based Learning $(P B L)$ dapat meningkatkan keterampilan sosial siswa kelas XI TITL SMK Gamaliel 1 Madiun, hal tersebut nampak pada peningkatan proses pembelajaran melalui pengamatan yang dilakukan terhadap siswa eroleh skor rata-rata indikator keterampilan sosial yang meningkat dari siklus I sebesar 61,23 menjadi 72,03 pada siklus II serta menjadi 82,09 pada siklus III. Demikian aktivitas guru dalam pembelajaran juga meningkat hal ini dapat dilihat dari hasil pengamatan yang dilakukan terhadap aktivitas guru pada siklus I diperoleh skor sebesar 76,92 meningkat menjadi 84,62 pada siklus II dan meningkat 96,15 pada siklus III. (2) Penerapan model pembelajaran Problem Based Learning (PBL) dapat meningkatkan hasil belajar siswa kelas XI TITL SMK Gamaliel 1 Madiun, hal ini nampak pada peningkatan nilai rata-rata tes hasil belajar berbasis aplikasi moodle dari siklus I sebesar 65,00 menjadi 71,14 pada siklus II serta menjadi 76,71 pada siklus III. Sehingga pada akhir siklus III sebesar 83,86\% secara klasikal telah melampaui kriteria ketuntasan minimal yang telah ditetapkan yakni sebesar $70 \%$.
Abate, L.L \& Milan, M.A. (1985), Handbook of Social Skills Training and Reseach, New York: John Wisley and Son.

Arikunto Suharsimi, Suhardjono, Supardi. (2006). Penelitian Tindakan Kelas. Jakarta : Bumi Aksara

Azhar Arsyad, M.A. (2002), Media Pembelajaran. Jakarta: Rajawali Pers

Bawden, D. (2001). Information and digital literacies: a review of concepts. Journal of documentation, 57(2), 218-259. Diakses pada tanggal 18 Juni 2019.

https://arizona.openrepository.com/ bitstream/handle/10150/ 105803/bawden.pdf;jsessionid $=$ AB7 4D57F437985EC8DF48D6343BC7B3 A? sequence $=1$.

Depdiknas, (2006). Permendiknas No 22 Tahun 2006 Tentang Standar Isi. Jakarta: Depdiknas.

Gimpel, G. A., \& Merrell, K. W. (1998). Social Skills of Children and Adolescent: Conceptualization, Assessment, Treatment. New Jersey: Lawrence Erlbaurn Associates Publisher.

Hiemstra, R. (1994). Self Directed learning. Diakses pada tanggal 10 Agustus 2019 dari: ccnmtl.columbia.edu/projects/pl3p/ Self-Directed\%20 Learning.pdf

Huda, M. (2013). Model-Model Pengajaran dan Pembelajaran: Isu-Isu Metodis dan Paradigmatis. Yogyakarta: Pustaka Pelajar.

I.G.A.K. Wardani. (2007). Penelitian Tindakan Kelas. Jakarta: Universitas Terbuka KTSP SD/MI 2011.

Izzaty, R.E. (2007), Perkembangan Peserta Didik, Yogyakarta, UNY Press.

Malikeh Beheshtifar, (2013), Social Skills: A Factor to Employees Success, Internasional Journal of Academic Research in Bussiness anda Social Sciences, March 2013 Vol.3 No.3, ISSN 2222-6990, Diakses tanggal 2 September 2019.

Maryani, Enok. (2011). Pengembangan Program Pembelajaran IPS Untuk Peningkatan Keterampilan Sosial. Alfabeta: Bandung 
Muhibbin Syah, (2013), Psikologi pendidikan dengan pendekatan baru, Jakarta: PT Remaja Rosdakaraya.

Ngalimun. 2012. Strategi dan Model Pembelajaran. Banjarmasin: Aswaja Pressindo

Rusman. (2013). Metode-Metode Pembelajaran: Mengembangkan Profesionalisme Guru. Jakarta: PT Raja Grafindo Persada.

Saripah, I \& Mulyani, L. (2015). Profil keterampilan sosial siswa sekolah dasar berdasarkan latar belakang pendidikan prasekolah (TK dan non TK). Mimbar Sekolah Dasar, Vol 2(2) 2015, 152-166.

Slameto, (2013), Belajar Dan Faktor-Faktor Yang Mempengaruhi, Jakarta: Rineka Cipta.

Suwarsih, Madya. (1994). Panduan Penelitian Tindakan. Yogyakarta : Lembaga Penelitian IKIP Yogyakarta.

Undang-Undang Nomor 20 Tahun 2003 Tentang Sistem Pendidikan Nasional. 